\title{
Transfer of Streptosporangium viridogriseum (Okuda et al. 1966), Streptosporangium viridogriseum subsp. kofuense (Nonomura and Ohara 1969), and Streptosporangium albidum (Furumai et al. 1968) to Kutzneria gen. nov. as Kutzneria viridogrisea comb. nov., Kutzneria kofuensis comb. nov., and Kutzneria albida comb. nov., Respectively, and Emendation of the Genus Streptosporangium
}

\author{
E. STACKEBRANDT, ${ }^{1,2 *}$ R. M. KROPPENSTEDT, ${ }^{1}$ K.-D. JAHNKE, ${ }^{1}$ C. KEMMERLING, ${ }^{2}$ AND H. GÜRTLER ${ }^{3}$ \\ Deutsche Sammlung von Mikroorganismen und Zellkulturen, D-38124 Braunschweig, Germany ${ }^{1}$; Department of \\ Microbiology, Centre for Bacterial Diversity and Identification, The University of Queensland, St. Lucia, \\ Queensland 4065, Australia ${ }^{2}$; and Novo BioKontrol, Novo Nordisk A/S, Bagsvaerd 2880, Denmark ${ }^{3}$
}

\begin{abstract}
A chemotaxonomic analysis of 14 Streptosporangium species revealed the phenotypic heterogeneity of this genus. The type species, Streptosporangium roseum, and 11 other species share similar isoprenoid quinones, fatty acids, and polar lipids. Two species, Streptosporangium albidum and Streptosporangium viridogriseum, including $S$. viridogriseum subsp. viridogriseum and $S$. viridogriseum subsp. kofuense, were characterized by a pattern of chemotaxonomic properties that was clearly distinct from the pattern obtained for the authentic Streptosporangium species. The results of a previous phylogenetic analysis of 16S ribosomal DNA and 5S rRNA indicated that the type species and its relatives are distantly related to members of the genus Streptomyces, whereas a member of the other group was found to be phylogenetically related to, but clearly distinct from, members of the family Pseudonocardiaceae. On the basis of these phenotypic and genomic differences, we propose the name Kutzneria gen. nov. for a new genus containing the previously misclassified Streptosporangium species and describe Kutzneria viridogrisea comb. nov., Kutzneria albida comb. nov., and Kutzneria kofuensis comb. nov. The type species of the new genus is Kutzneria viridogrisea, and the type strain is DSM 43850 (= ATCC 25242).
\end{abstract}

The actinomycete family Streptosporangiaceae (3) presently contains the genera Streptosporangium, Microbispora, Microtetraspora (including the former Actinomadura pusilla group), Planomonospora, and Planobispora, as well as the recently described genus Herbidospora (11) and, tentatively, the genus Spirillospora. Given the presence of a phylogenetic branching pattern, a combination of properties such as wall chemotype, peptidoglycan type, whole-cell sugars, fatty acid and phospholipid profiles, and menaquinones $(2,8)$ facilitates the delineation of actinomycete genera from neighboring taxa. Unfortunately, the paucity of distinctive chemotaxonomic properties of Streptosporangium species has led workers to believe that this genus is a phylogenetically, morphologically, and chemotaxonomically homogeneous taxon, and consequently only the type species of the genus Streptosporangium, Streptosporangium roseum, was included in previous phylogenetic studies of sporoactinomycetes $(24,25)$. However, the results of a recent analysis of morphological properties of spores and spore vesicles detected by scanning electron microscopy (18), an analysis of the electrophoretic mobility of ribosomal protein AT-L30 (20), and an analysis of 16S ribosomal DNA (rDNA) (5) and 5S rRNA (11) indicated that the members of this genus are heterogeneous phenotypically and genomically. In this paper we describe the chemotaxonomic properties of members of the genus Streptosporangium, and, on the basis of the results of a polyphasic approach to bacterial classification, we propose

\footnotetext{
* Corresponding author. Mailing address: Deutsche Sammlung von Mikroorganismen und Zellkuturen, Mascheroder Weg 1B, D-36124 Brauschweig, Germany. Phone: 495312616 352. Fax: 495312616418.
}

creation of the genus Kutzneria gen. nov. and the species Kutzneria viridogrisea comb. nov., Kutzneria kofuensis comb. nov., and Kutzneria albida comb. nov.

\section{MATERIALS AND METHODS}

Strains and culture conditions. The Streptosporangium strains investigated are listed in Table 1 . Cells were grown on solidified DSM medium 65 (1) at $28^{\circ} \mathrm{C}$ for 2 to 3 days.

Analysis of cell wall amino acids and sugars. For amino acid and sugar analyses of whole-cell hydrolysates we used previously described procedures (26).

Extraction and analysis of isoprenoid quinones and polar lipids. Isoprenoid quinones were extracted and purified by using the small-scale integrated procedure of Minnikin et al. (17). Dried preparations were dissolved in $200 \mu \mathrm{l}$ of isopropanol, and 1- to $10-\mu l$ portions were injected into high-performance liquid chromatography (HPLC) column without further purification. Menaquinones were separated with a Lichrosorb RP-18 column ( 4 by $250 \mathrm{~mm}$ ) kept at $40^{\circ} \mathrm{C}$ by using acetonitrile-isopropanol $(65: 35, \mathrm{vol} / \mathrm{vol})$ as the solvent (10). A silverloaded ion exchanger was used to separate positional isomers of the isoprene side chains of the menaquinones (9). Polar lipids were extracted, examined by two-dimensional thin-layer chromatography, and identified by using previously described procedures (17).

Extraction and analysis of fatty acids. Fatty acid methyl esters were obtained from freeze-dried biomass (approximately $10 \mathrm{mg}$ ) by saponification, methylation, and extraction, using minor modifications (12) of the method of Miller (16). The fatty acid methyl ester mixtures were separated by using a 
TABLE 1. Strains investigated and phospholipids in members of the genera Streptosporangium and Kutzneria

\begin{tabular}{|c|c|c|c|c|c|}
\hline Species & $\mathrm{PE}^{a}$ & $\mathrm{OH}-\mathrm{PE}$ & NPG & DPG & PI \\
\hline $\begin{array}{l}\text { Streptosporangium album DSM } \\
43023^{\mathrm{Th}}\end{array}$ & + & + & + & + & + \\
\hline $\begin{array}{l}\text { Streptosporangium amethystogenes } \\
\text { DSM } 43179^{\mathrm{T}}\end{array}$ & + & + & + & + & + \\
\hline Streptosporangium fragile DSM $43847^{\mathrm{T}}$ & + & + & + & + & + \\
\hline $\begin{array}{l}\text { Streptosporangium longisporum DSM } \\
43180^{\mathrm{T}}\end{array}$ & + & + & + & + & + \\
\hline $\begin{array}{l}\text { Streptosporangium nondiastaticum } \\
\text { DSM } 43848^{\mathrm{T}}\end{array}$ & $\mathrm{ND}^{c}$ & ND & ND & ND & ND \\
\hline $\begin{array}{l}\text { Streptosporangium pseudovulgare DSM } \\
43181^{\mathrm{T}}\end{array}$ & + & + & + & + & + \\
\hline $\begin{array}{l}\text { Streptosporangium roseum DSM } \\
43021^{\mathrm{T}}\end{array}$ & + & + & + & + & + \\
\hline $\begin{array}{l}\text { Streptosporangium violaceochromogenes } \\
\text { DSM } 43849^{\mathrm{T}}\end{array}$ & ND & ND & ND & ND & ND \\
\hline $\begin{array}{l}\text { Streptosporangium viridialbum DSM } \\
4^{43801^{\mathrm{T}}}\end{array}$ & + & + & + & + & + \\
\hline $\begin{array}{l}\text { Streptosporangium vulgare DSM } \\
43802^{\mathrm{T}}\end{array}$ & + & + & + & + & + \\
\hline $\begin{array}{l}\text { Streptosporangium carneum NRRL } \\
18437^{\mathrm{T} d}\end{array}$ & + & - & - & + & + \\
\hline $\begin{array}{l}\text { Streptosporangium corrugatum DSM } \\
43316^{\mathrm{T}}\end{array}$ & + & + & - & + & + \\
\hline Kutzneria viridogrisea DSM $43850^{\mathrm{T}}$ & + & + & - & + & + \\
\hline Kutzneria kofuensis DSM $43851^{\mathrm{T}}$ & + & + & - & + & + \\
\hline Kutzneria albida DSM $43870^{\mathrm{T}}$ & + & + & - & + & + \\
\hline
\end{tabular}

${ }^{a} \mathrm{PE}$, phosphatidylethanolamine; OH-PE, hydroxyphosphatidylethanolamine; NPG, ninhydrin-positive and sugar-positive phospholipids; DPG, disphosphatidylglycerol; PI, posphatidylinositol.

${ }_{b} \mathrm{~T}=$ type strain.

${ }^{c} \mathrm{ND}$, not determined.

${ }^{d}$ Data from reference 14

model 5898A microbial identification system (Microbial ID, Inc., Newark, Del.), which consisted of a Hewlett-Packard model 3392 gas chromatograph fitted with a $5 \%$ phenylmethyl silicone capillary column $(0.2 \mathrm{~mm}$ by $25 \mathrm{~m})$, a flame ionization detector, a Hewlett-Packard model 3392 integrator, a HewlettPackard model 7673A automatic sampler, and a HewlettPackard model 900/300 computer (Hewlett-Packard Co., Palo
Alto, Calif.). Peaks were automatically integrated, and fatty acid names and percentages were determined by using the Microbial ID system. The gas chromatographic parameters were as follows: carrier gas, ultra-high-purity hydrogen; column head pressure, $60 \mathrm{kPa}$; injection volume, $2 \mu \mathrm{l}$; column split ratio, 100:1; septum purge rate, $5 \mathrm{ml} / \mathrm{min}$; column temperatures, 170 to $270^{\circ} \mathrm{C}$ (increased at a rate of $5^{\circ} \mathrm{C} / \mathrm{min}$ ); injection port temperature, $250^{\circ} \mathrm{C}$; and detector temperature, $300^{\circ} \mathrm{C}$.

Determination of the DNA $\mathbf{G}+\mathbf{C}$ content. DNA was isolated by using previously described procedures (28). Approximately $20 \mu \mathrm{g}$ of DNA was hydrolyzed and dephosphorylated as described previously (15). Nucleosides were separated by reverse-phase HPLC. The apparatus used consisted of an LKB model 2150 high-pressure pump equipped with an LKB model 2151 UV detector $(270 \mathrm{~nm})$ connected to a Shimadzu model CR-3A integrator. The analytical column was a NUCLEOSIL $100-5 \mathrm{C} 18$ column ( 240 by $4 \mathrm{~mm}$ ) equipped with a NUCLEO SIL $100-5$ C18 precolumn ( 20 by $4 \mathrm{~mm}$ ); the solvent system used was the solvent system of Tamaoka and Komagata (27). The retention times of the nucleosides were determined with synthetic compounds. Nonmethylated lambda phage DNA with a $\mathrm{G}+\mathrm{C}$ content of $49.858 \mathrm{~mol} \%$ (22) was used as a calibration reference. The $\mathrm{G}+\mathrm{C}$ contents were calculated automatically with the Shimadzu integrator.

\section{RESULTS AND DISCUSSION}

Chemotaxonomic properties have been found to be important contributors to the polyphasic approach to bacterial systematics, especially for the circumscription of phylogenetically coherent actinomycete taxa $(2,7)$. As a result of studies described previously $(5,11,18,20)$ and in this paper, we believe that certain species should not be retained in the genus Streptosporangium. The genus name Kutzneria is proposed below for these species; Tables 1 to 3 show chemotaxonomic properties of these organisms.

In contrast to the results of morphological studies (18) and an analysis of ribosomal protein components (20), which indicated that there are three Streptosporangium species clusters (represented by $S$. roseum, Streptosporangium corrugatum, and Streptosporangium viridogriseum), in this study only two

TABLE 2. Whole-cell sugars and menaquinone compositions of members of the genera Streptosporangium and Kutzneria

\begin{tabular}{|c|c|c|c|c|c|c|c|c|c|c|}
\hline \multirow[b]{2}{*}{ Species } & \multicolumn{3}{|c|}{ Whole-cell sugars } & \multicolumn{7}{|c|}{ Menaquinone composition $(\%)^{a}$} \\
\hline & Galactose & Madurose & Rhamnose & $\begin{array}{l}\text { Mk-8 } \\
\left(\mathrm{H}_{4}\right)\end{array}$ & $\begin{array}{l}\text { MK-9 } \\
\left(\mathrm{H}_{0}\right)\end{array}$ & $\begin{array}{l}\text { MK-9 } \\
\left(\mathrm{H}_{2}\right)\end{array}$ & $\begin{array}{c}\text { MK-9 } \\
\left.\text { (III,VIII-H }{ }_{4}\right)\end{array}$ & $\begin{array}{c}\text { MK-9 } \\
(\text { II }, \text { III-H }\end{array}$ & $\begin{array}{c}\text { MK-9 } \\
\left(\mathrm{H}_{6}\right)\end{array}$ & $\begin{array}{c}\text { MK-10 } \\
\left(\mathrm{H}_{4}\right)\end{array}$ \\
\hline Streptosporangium album & + & $\operatorname{tr}$ & - & & & & & & & \\
\hline Streptosporangium amethystogenes & - & + & - & & 10.1 & 49.4 & 33.5 & & & \\
\hline Streptosporangium fragile & - & - & - & & & 15.0 & 60.0 & & 25.0 & \\
\hline Streptosporangium longisporum & - & + & - & & 12.7 & 35.1 & 45.0 & & 7.2 & \\
\hline Streptosporangium nondiastaticum & - & - & - & & 2.0 & 55.0 & 40.0 & & 3.0 & \\
\hline Streptosporangium pseudovulgare & - & + & - & & 11.6 & 60.4 & 28.0 & & & \\
\hline Streptosporangium roseum & + & + & - & & 5.0 & 37.8 & 56.5 & & 0.7 & \\
\hline Streptosporangium violaceochromogenes & - & - & - & & 19.0 & 50.0 & 31.0 & & & \\
\hline Streptosporangium viridialbum & - & + & - & & 35.3 & 42.8 & 21.9 & & & \\
\hline Streptosporangium vulgare & - & + & - & & 38.2 & 46.7 & 15.1 & & & \\
\hline Streptosporangium carneum ${ }^{b}$ & - & + & - & & & ++ & +++ & & & \\
\hline Streptosporangium corrugatum & + & $\operatorname{tr}$ & - & & 12.9 & 52.3 & 32.4 & & 3.4 & \\
\hline Kutzneria viridogrisea & + & - & + & 1.0 & & 3.0 & & 90.0 & 4.0 & 2.0 \\
\hline Kutzneria albida & - & - & & & & & & 100.0 & & \\
\hline Kutzneria kofuensis & + & - & & 1.0 & & & & 97.0 & & 2.0 \\
\hline
\end{tabular}

${ }^{a}$ The designations indicate the number of isoprenyl groups in the side chain and the number of hydrogenated double bonds.

${ }^{b}$ Data from reference 14 (no qualitative data available). 
TABLE 3. Fatty acid patterns of the genera Streptosporangium, Kutzneria, and Saccharothrix ${ }^{n}$

\begin{tabular}{lccc}
\hline & \multicolumn{3}{c}{ Mean \% in: } \\
\cline { 2 - 4 } Fatty acid & $\begin{array}{c}\text { Streptosporangium } \\
\text { (9 strains) }\end{array}$ & $\begin{array}{c}\text { Kutzneria } \\
(4 \text { strains) }\end{array}$ & $\begin{array}{c}\text { Saccharothrix } \\
\text { (10 strains) }\end{array}$ \\
\hline 13:0 & 0.69 & & \\
iso-14:0 & 4.84 & & 2.52 \\
14:0 & 1.79 & & \\
iso-15:0 & 3.66 & 2.71 & 12.73 \\
anteiso-15:0 & 1.98 & & 3.16 \\
15:1 & & & 0.53 \\
15:0 & 5.12 & 1.61 & 0.90 \\
iso-16:1 & & 0.56 & 5.54 \\
iso-16:0 & 12.27 & 30.28 & 37.01 \\
cis9-16:1 & 3.51 & 3.80 & 1.49 \\
2-OH-iso-15:0 & & & 1.20 \\
16:0 & 10.07 & 6.16 & 1.74 \\
Unknown ECL 16.048 & & & 2.51 \\
9-methyl-16:0 & & & 4.46 \\
10-methyl-16:0 & 3.97 & 8.58 & \\
iso-17:0 & 1.45 & 6.19 & 3.48 \\
anteiso-17:0 & 1.14 & 7.45 & 6.48 \\
cis9-17:1 & 10.90 & 2.71 & 4.40 \\
2-OH-iso-16:0 & 1.17 & 11.67 & 4.03 \\
17:0 & 10.00 & 4.26 & 1.58 \\
2-OH-16:0 & 0.82 & & \\
10-methyl-17:0 & 15.00 & 5.87 & 1.28 \\
iso-18:0 & 0.77 & 0.86 & 0.55 \\
cis9-18:1 & 2.99 & 0.83 & 0.67 \\
2-OH-anteiso-17:0 & & 4.48 & 0.78 \\
18:0 & 2.20 & & \\
10-methyl-18:0 & 2.73 & 1.49 & \\
\hline
\end{tabular}

${ }^{a}$ Data from reference 4.

main clusters emerged (represented by $S$ roseum and $S$. viridogriseum). The members of each of these clusters are characterized by high levels of similarity in whole-cell sugars, menaquinones, fatty acid patterns, and phospholipid patterns; however, there are significant differences between the characteristics of the two species clusters. All Streptosporangium species defined previously (2) have in common wall chemotype III (i.e., meso-diaminopimelic acid [13]), fatty acid pattern 3c (i.e., saturated, unsaturated, iso and anteiso, and 10-methyl branched fatty acids [6], as well as 2-hydroxy fatty acids [7]), a DNA base composition between 69 and 71 mol\% (as determined by the thermal denaturation method), and a lack of diagnostic sugars. In contrast to the description of the genus (18), madurose was not found in all species. The majority of species, including type species $S$. roseum but also $S$. corrugatum, are defined by the following combination of characteristics: the principal menaquinones are $\mathrm{MK}-9\left(\mathrm{H}_{2}\right)$ and MK9(II,VIII- $\left.\mathrm{H}_{4}\right)$, MK-9, and/or MK-9 $\left(\mathrm{H}_{6}\right)$ and the phospholipid type is type IV. The other cluster is composed of the two subspecies of $S$. viridogriseum and Streptosporangium albidum. These organisms are characterized by principal isoprenoids of the MK-9(II, III- $\mathrm{H}_{4}$ ) type and by phospholipid type II; the DNA $\mathrm{G}+\mathrm{C}$ contents of these organisms range between 70.3 and 70.7 mol\% (this study).

The clustering of species based on morphological and chemotaxonomic properties is consistent with the results of a phylogenetic analysis of representatives of the two clusters. A $16 \mathrm{~S}$ rDNA analysis (5) revealed that type species $S$. roseum, Streptosporangium nondiastaticum, and Streptosporangium pseudovulgare were closely related (similarity level, 97.3 to $99.4 \%$ ). These three species exhibited a close relationship to $S$. corrugatum (similarity levels, 94.4 to $94.7 \%$ ). These four species were moderately closely related to members of the genus Streptomyces (similarity levels, 91.1 to $91.8 \%$ ). The results of a recent $5 \mathrm{~S}$ rRNA analysis confirmed this conclusion; members of the family Streptosporangiaceae were found to be phylogenetic neighbors of members of the family Streptomycetaceae (11). On the other hand, the results of both analyses indicated that $S$. viridogriseum subsp. viridogriseum was clearly less closely related to the other Streptosporangium species (16S rDNA similarity levels, 90.8 to $91.7 \%$ ) and clustered with members of the family Pseudonocardiaceae (16S rDNA similarity levels, 92.5 to $94.9 \%$ ) particularly Saccharothrix australiensis (16S rDNA similarity level, 94.9\%) (5).

The results of investigations described above clearly show that two species of the genus Streptosporangium, S. albidum and $S$. viridogriseum, including $S$. viridogriseum subsp. viridogriseum and $S$. viridogriseum subsp. kofuense, should not be retained in the genus Streptosporangium. The differences in the primary structures of both 5SrRNA and 16S rRNA, as well as in chemotaxonomic properties and in the electrophoretic mobility of a ribosomal protein, between members of the two clusters are greater than the differences that separate genera belonging to the family Streptosporangiaceae. The genus Streptosporangium should be restricted to the type species, $S$. roseum, and its relatives. Although there are substantial differences in the primary structure of $16 \mathrm{~S}$ rRNA between $S$. roseum and $S$. corrugatum (5) and apparently in the amino acid sequence of the AT-L30 protein (20), the differences observed in the chemotaxonomic properties investigated so far are too small to consider $S$. corrugatum a representative of a novel genus. However, workers should be prepared to describe a new genus for $S$. corrugatum when differences in other phenotypic characteristics that have taxonomic value are discovered.

The phylogenetic position of $S$. viridogriseum and its relatives is within the confines of the family Pseudonocardiaceae, adjacent to Saccharothrix australiensis (5). No obvious exclusive chemotaxonomic features are shared by these organisms and the misclassified Streptosporangium species. The phylogenetic distance between Saccharothrix australiensis and the misclassified Streptosporangium species and the differences in morphology and in the fatty acid and menaquinone patterns, are significant enough to justify the description of a new genus, for which the name Kutzneria is proposed. Table 4 shows the key characteristics which differentiate the genera Kutzneria and Streptosporangium and phenotypically and genomically related genera. Below we also emend the descriptions of the species $K$. viridogriseum and $K$. albida. The unpublished results of DNA similarity studies (1b) indicate that the two subspecies of $S$. viridogriseum exhibit less than $15 \%$ DNA similarity, whereas $S$. viridogriseum subsp. viridogriseum and $S$. albidum exhibit more than $30 \%$ DNA similarity. This relationship is also reflected by similarities in the fatty acid patterns (Fig. 1). Therefore, we propose that $S$. viridogriseum subsp. kofuense should be elevated to species status as Kutzneria kofuensis. The type species of the genus Kutzneria is $K$. viridogrisea because the original description of $S$. viridogriseum (21) has priority over $S$. albidum (1a) and $S$. viridogriseum subsp. kofuensis (19). The species description is the same as the original description except that it is emended to include chemotaxonomic data.

Description of the genus Kutzneria. Kutzneria (Kutz.ne'ri.a. M.L. fem. n. Kutzneria, named after Hans-Jürgen Kutzner, a German microbiologist). The description of morphological characteristics below is taken from the descriptions of the genus Streptosporangium and group 1 streptosporangia (18). Stable, branched, cottony aerial mycelium. Globose sporangia are large (diameter, 10 to $48 \mu \mathrm{m}$ ). Sporangial walls are thick 
TABLE 4. Comparison of the genus Kutzneria with phenotypically and phylogenetically related genera of actinomycetes

\begin{tabular}{|c|c|c|c|c|c|c|c|}
\hline \multirow[b]{2}{*}{ Genus } & \multicolumn{3}{|c|}{ Morphology } & \multicolumn{4}{|c|}{ Chemotaxonomy } \\
\hline & $\begin{array}{c}\text { Aerial } \\
\text { mycelium }\end{array}$ & Sporangium & $\begin{array}{l}\text { Motile } \\
\text { spores }\end{array}$ & $\begin{array}{l}\text { Whole-cell } \\
\text { sugar type }\end{array}$ & $\begin{array}{l}\text { Phospholipid } \\
\text { type }\end{array}$ & $\begin{array}{l}\text { Fatty acid type } \\
(>10 \% \text { of total })\end{array}$ & Major menaquinone(s) \\
\hline Kutzneria & + & + & - & E & II & $3 \mathrm{c}$ & MK-9(II,III-H 4$)$ \\
\hline Saccharothrix & + & - & - & $\mathrm{C}$ & II & $3 \mathrm{f}$ & MK-9(II,III-H 4$),$ MK-10(II,III-H $\left.{ }_{4}\right)$ \\
\hline Kibdelosporangium & + & $t^{a}$ & - & A & II & $3 \mathrm{c}$ & $\mathrm{ND}^{b}$ \\
\hline Streptosporangium & + & + & - & $\mathrm{B}$ or $\mathrm{C}$ & IV & $3 \mathrm{c}$ & $\begin{array}{l}\text { MK-9 }\left(\mathrm{H}_{0}\right), \text { MK-9 }\left(\mathrm{H}_{2}\right), \text { MK-9(III, } \\
\left.\text { VIII-H } \mathrm{H}_{4}\right)\end{array}$ \\
\hline Planomonospora & + & + & + & B & IV & $3 \mathrm{c}$ & $\begin{array}{l}\text { MK-9 }\left(\mathrm{H}_{0}\right), \text { MK-9 }\left(\mathrm{H}_{2}\right), \text { MK-9(III, } \\
\left.\text { VIII-- } H_{4}\right)\end{array}$ \\
\hline Microtetraspora & + & - & - & $\mathrm{B}$ or $\mathrm{C}$ & IV & $3 \mathrm{c}$ & $\begin{array}{l}\text { MK-9 }\left(\mathrm{H}_{0}\right), \text { MK-9 }\left(\mathrm{H}_{2}\right), \text { MK-9(III, } \\
\left.\text { VIII- } \mathrm{H}_{4}\right)\end{array}$ \\
\hline Microbispora & + & - & - & B & IV & $3 c$ & MK-9( $\left.\mathrm{H}_{2}\right)$, MK-9(III, VIII-H $\left.{ }_{4}\right)$ \\
\hline Herbidospora & - & - & - & B & IV & $3 \mathrm{c}$ & $\begin{array}{l}\text { MK-10(III,IX-H })_{4}, \text { MK-10 }\left(\mathrm{H}_{6}\right), \\
\text { MK-10 }\left(\mathrm{H}_{2}\right)\end{array}$ \\
\hline Actinomadura & + & - & - & B & I & $3 \mathrm{a}$ & MK-9 $\left(\mathrm{H}_{6}\right)$, MK-9 $\left(\mathrm{H}_{8}\right)$ \\
\hline Spirillospora & + & + & + & B & I or II & $3 \mathrm{a}$ & MK-9 $\left(\mathrm{H}_{4}\right)$, MK-9( $\left.\mathrm{H}_{6}\right)$ \\
\hline
\end{tabular}

${ }^{a}$ Sporangium-like structures do not contain spores but germinate directly (23).

${ }^{b} \mathrm{ND}$, not determined.

and strong. Long sporangiophores more than $50 \mu \mathrm{m}$ long are formed by septation of coiled, unbranched hyphae within the sporangiophores. The spores are spherical, rod shaped, or oval and nonmotile. Aerobic. Mesophilic. Some species are thermotolerant. Chemoorganotrophic. Gram positive. Cell walls contain $\mathrm{N}$-acetylated muramic acid, meso-diaminopimelic acid, and no common characteristic sugars. MK-9(II, III- $\mathrm{H}_{4}$ ) is the major isoprenolog. The major phospholipids usually include phosphatidylethanolamine, hydroxyphosphatidylethanolamine, phosphatidylinositol, and diphosphatidylglycerol. Iso-16:0, 2-OH-iso-16:0, 10-methyl-16:0, anteiso-17:0, and 2$\mathrm{OH}$-anteiso-17:0 fatty acids are major fatty acids. No 13:0, iso-14:0, and 14:0 fatty acids are present. Natural habitat: soil. The $\mathrm{G}+\mathrm{C}$ content of the DNA is 70.3 to $70.7 \mathrm{~mol} \%$ (as

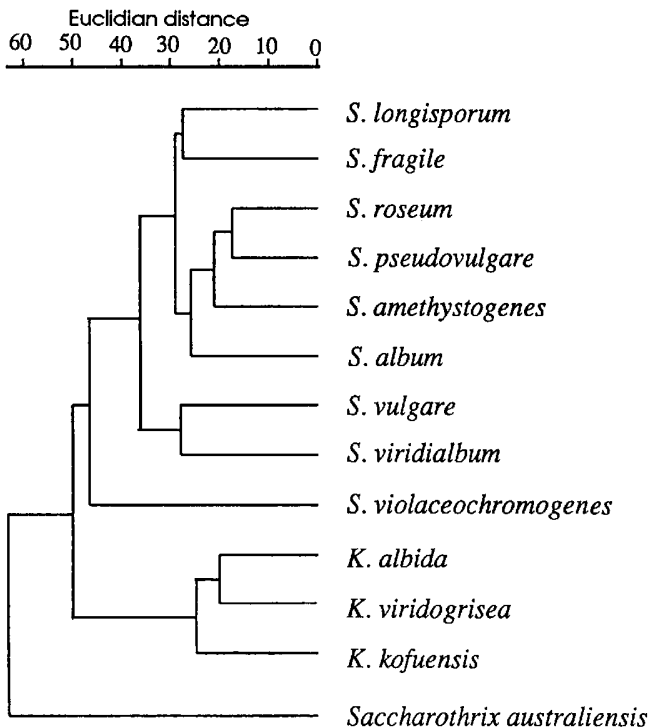

FIG. 1. Cluster analysis of fatty acid profiles of Streptosporangium and Kutzneria species. The branching pattern was constructed from Euclidian distance coefficients by the unweighted pair group method with arithmetric averages. The analysis was performed by using the standard MIS software (Microbial ID). determined by HPLC). Phylogenetically related to Saccharothrix australiensis.

The type species is Kutzneria viridogrisea.

Description of Kutzneria viridogrisea (Okuda, Furumai, Watanabe, Okugawa, and Kimura 1966) comb. nov. (Approved Lists 1980). Kutzneria viridogrisea (vi.ri.do.gri' se.a. L. adj. viridis, green; L. adj. griseus, gray; M.L. fem. adj. viridogrisea, greenish gray). Descriptions of this taxon have been published previously by Okuda et al. (21) and Nonomura (18). The whole-cell sugars are galactose and rhamnose. The DNA G+C content is $70.3 \mathrm{~mol} \%$. Type strain: DSM 43850 (= ATCC 25242).

Description of Kutzneria albida (Furumai, Ogawa, and Okuda 1968) comb. nov. (Approved Lists 1980). Kutzneria albida (al'bi.da. L. fem. adj. albidum, white). Descriptions of this taxon have been published previously by Furumai et al. (1a) and Nonomura (18). The whole-cell sugar is rhamnose. The DNA G+C content is $70.7 \mathrm{~mol} \%$. Type strain: DSM 43870 (= ATCC 25243).

Description of Kutzneria kofuensis (Nonomura and Ohara 1969) comb. nov. (Approved Lists 1980). Kutzneria kofuensis (ko.fu.en'sis. M.L. adj. kofuensis, belonging to Kofu, a district in Japan, where the organism was isolated). Descriptions of this taxon have been published previously by Nonomura and Ohara (19) and Nonomura (18). The whole-cell sugars are rhamnose and galactose. The DNA $\mathrm{G}+\mathrm{C}$ content is 70.6 mol\%. Type strain: DSM 43851 (= ATCC 27102).

The exclusion of species from the genus Streptosporangium and the chemotaxonomic properties justify emendation of the description of this genus.

Description of the genus Streptosporangium Couch 1955 , $148^{\mathrm{AL}}$ emend. Stackebrandt et al. 1994. The description below is based on the characteristics given by Nonomura (18). Stable branched mycelium produces globose sporangia up to $10 \mu \mathrm{m}$ in diameter on the aerial mycelium. The sporangiophores are short (up to $10 \mu \mathrm{m}$ long). The sporangiospores are spherical-oval or rod shaped ( 0.2 to 1.3 by 0.2 to $1.5 \mu \mathrm{m}$ ) and nonmotile and are formed by septation of a coiled, unbranched hypha within the sporangium. Cell walls contain $\mathrm{N}$-acetylated muramic acid and meso-diaminopimelic acid, but no characteristic sugar occurs in whole-cell hydrolysates. Madurose may be present. The major phospholipids include phosphatidylethanolamine, hydroxyphosphatidylethanolamine, phosphatidylinositol, diphosphatidylglyc- 
erol, and an $\mathrm{N}$-acetylglucosamine-containing phospholipid but no phosphatidylcholine. The predominant menaquinones are MK-9 $\left(\mathrm{H}_{2}\right)$ and MK-9(II,VIII-H $\left.{ }_{4}\right)$, MK-9, and/or MK-9 $\left(\mathrm{H}_{6}\right)$. The characteristic fatty acids are 13:0, iso-14:0, 14:0, 15:0, iso-16:0, cis $9-16: 1,16: 0,10$-methyl-16:0, cis $9-17: 1,17: 0,10$-methyl-17:0, and 18:0 fatty acids. $2-\mathrm{OH}$-iso-16:0 fatty acid is present. No 2-OH-anteiso-17:0 fatty acid is present. Gram positive. Aerobic. Mesophilic. Chemoorganotrophic. Some species require vitamin B for growth. Natural habitat: soil. The $\mathrm{G}+\mathrm{C}$ content of the DNA is 69 to $71 \mathrm{~mol} \%$ (as determined by the thermal denaturation method). Type species: Streptosporangium roseum Couch 1955, 151.

\section{ACKNOWLEDGMENTS}

This study was supported in part by a grant from Novo/Nordisk, Bagsvaerd, Denmark.

We thank George Garrity for providing unpublished DNA similarity data.

\section{REFERENCES}

1. Deutsche Sammlung von Mikroorganismen und Zellkulturen. 1993. Catalogue of strains. Deutsche Sammlung von Mikroorganismen und Zellkulturen, Braunschweig, Germany.

1a.Furumai, T., H. Ogawa, and T. Okuda. 1968. Taxonomic study on Streptosporangium albidum sp. nov. J. Antibiot. (Tokyo) 21:179181.

1b.Garrity, G. (Merck). Personal communication.

2. Goodfellow, M. 1991. The family Streptosporangiaceae, p. 11151138. In A. Balows, H. G. Trüper, M. Dworkin, W. Harder, and K. H. Schleifer (ed.), The prokaryotes, 2nd ed. Springer, New York.

3. Goodfellow, M., L. J. Stanton, K. E. Simpson, and D. E. Minnikin. 1990. Numerical and chemical classification of Actinoplanes and some related actinomycetes. J. Gen. Microbiol. 136:19-36.

4. Grund, E., and R. M. Kroppenstedt. 1989. Transfer of five Nocardiopsis species to the genus Saccharothrix Labeda et al. 1984. Syst. Appl. Microbiol. 12:267-274.

5. Kemmerling, C., H. Gürtler, R. M. Kroppenstedt, R. Toalster, and E. Stackebrandt. 1993. Evidence for the phylogenetic heterogeneity of the genus Streptosporangium. Syst. Appl. Microbiol. 16:369372 .

6. Kroppenstedt, R. 1985. Fatty acid and menaquinone analysis of actinomycetes and related organisms, p. 173-199. In M. Goodfellow and D. E. Minnikin (ed.), Chemical methods in bacterial systematics. Academic Press, London.

7. Kroppenstedt, R., and M. Goodfellow. 1991. The family Thermomonosporaceae, p. 1085-1114. In A. Balows, H. G. Trüper, M. Dworkin, W. Harder, and K. H. Schleifer (ed.), The prokaryotes, 2nd ed. Springer, New York.

8. Kroppenstedt, R., E. Stackebrandt, and M. Goodfellow. 1990. Taxonomic revision of the actinomycete genera Actinomadura and Microtetraspora. Syst. Appl. Microbiol. 13:148-160.

9. Kroppenstedt, R. M. 1982. Separation of bacterial menaquinones by HPLC using reverse phase (RP 18) and a silver loaded ion exchanger as stationary phases. J. Liquid Chromatogr. 5:23592387.

10. Kroppenstedt, R. M., F. Korn-Wendisch, V. J. Fowler, and E. Stackebrandt. 1981. Biochemical and molecular genetic evidence for transfer of Actinoplanes armeniacus into the family Streptomycetaceae. Zentralbl. Bakteriol. Parasitenkd. Infektionskr. Hyg.
Abt. 1 Orig. Reihe C 2:254-262.

11. Kudo, T., T. Itoh, S. Miyadoh, T. Shomura, and A. Seino. 1993. Herbidospora gen. nov., a new genus of the family Streptosporangiaceae Goodfellow et al. 1990. Int. J. Syst. Bacteriol. 43:319-328.

12. Kuykendall, L. D., M. A. Roy, J. J. O'Neill, and T. E. Devine. 1988. Fatty acids, antibiotic resistance, and deoxyribonucleic acid homology groups of Bradyrhizobium japonicum. Int. J. Syst. Bacteriol. 38:358-361.

13. Lechevalier, M. P., and H. A. Lechevalier. 1970. Chemical composition as a criterion in the classification of aerobic actinomycetes. Int. J. Syst. Bacteriol. 20:435-443.

14. Mertz, F. P., and R. C. Yao. 1990. Streptosporangium carneum sp. nov. isolated from soil. Int. J. Syst. Bacteriol. 40:247-253.

15. Mesbah, M., U. Premachandran, and W. B. Whitman. 1989. Precise measurement of the $\mathrm{G}+\mathrm{C}$ content of deoxyribonucleic acid by high-performance liquid chromatography. Int. J. Syst. Bacteriol. 39:159-167.

16. Miller, L. T. 1982 . A single derivatization method for bacterial fatty acid methyl esters including hydroxy acids. J. Clin. Microbiol. 16:584-586.

17. Minnikin, D. E., A. G. O’Donnell, M. Goodfellow, G. Alderson, M. Athalye, K. Schaal, and J. H. Parlett. 1984. An integrated procedure for the extraction of isoprenoid quinones and polar lipids. J. Microbiol. Methods 2:233-241.

18. Nonomura, H. 1989. Genus Streptosporangium, p. 2545-2551. In S. T. Williams, M. E. Sharpe, and J. G. Holt (ed.), Bergey's manual of systematic bacteriology, vol. 4. The Williams \& Wilkins Co., Baltimore.

19. Nonomura, H., and Y. Ohara. 1969. Distribution of actinomycetes in soil. VII. A culture method effective for both preferential isolation and enumeration of Microbispora and Streptosporangium strains in soil (part 2). Classification of the isolates. J. Ferment. Technol. 47:701-709.

20. Ochi, K., and S. Miyadoh. 1992. Polyacrylamide gel electrophoresis analysis of ribosomal protein AT-L30 from an actinomycete genus, Streptosporangium. Int. J. Syst. Bacteriol. 42:151-155.

21. Okuda, T., T. Furumai, E. Watanabe, T. Okugawa, and S. Kimura. 1966. Actinoplanaceae antibiotics. II. Study of sporoviridin. 2. Taxonomic study of the sporoviridin producing microorganism: Streptosporangium viridogriseum sp. nov. J. Antibiot. Ser. A 19: 121-127.

22. Sanger, F., A. R. Coulson, G. F. Hong, D. F. Hill, and G. B. Petersen. 1982. Nucleotide sequence of bacteriophage lambda DNA. J. Mol. Biol. 162:729-773.

23. Shearer, M. C., P. M. Colman, R. M. Ferrin, L. J. Nisbet, and C. H. Nash. 1986. New genus of Actinomycetales: Kibdelosporangium aridum gen. nov., sp. nov. Int. J. Syst. Bacteriol. 36:47-54.

24. Stackebrandt, E., W. Ludwig, E. Seewaldt, and K. H. Schleifer. 1983. Phylogeny of sporeforming members of the order Actinomycetales. Int. J. Syst. Bacteriol. 33:173-180.

25. Stackebrandt, E., B. Wunner-Füssl, V. J. Fowler, and K. H. Schleifer. 1981. Deoxyribonucleic acid homologies and ribosomal ribonucleic acid similarities among sporeforming members of the order Actinomycetales. Int. J. Syst. Bacteriol. 31:420-431.

26. Stanek, J. L., and G. D. Roberts. 1974. Simplified approach to identification of aerobic actinomycetes by thin-layer chromatography. Appl. Microbiol. 28:226-231.

27. Tamaoka, J., and K. Komagata. 1984. Determination of DNA base composition by reverse-phase high-performance liquid chromatography. FEMS Microbiol. Lett. 25:125-128.

28. Visuvanathan, S., M. T. Moss, J. L. Stanford, J. Hermon-Taylor, and J. J. McFadden. 1989. Simple enzymatic method for isolation of DNA from diverse bacteria. J. Microbiol. Methods 10:59-64. 